\title{
deadpan, an essential pan-neural gene in Drosophila, encodes a helix-loop- helix protein similar to the hairy gene product
}

\author{
Ethan Bier, ${ }^{1,2}$ Harald Vaessin, ${ }^{1,3}$ Susan Younger-Shepherd, ${ }^{1}$ Lily Yeh Jan, ${ }^{1}$ and Yuh Nung Jan ${ }^{1}$ \\ ${ }^{1}$ Howard Hughes Medical Institute and the Departments of Physiology and Biochemistry, University of California at San \\ Francisco, San Francisco, California 94143 USA $^{2}$ Department of Biology and Center for Molecular Genetics, University of \\ California at San Diego, La Jolla, California 92093-0322 USA; ${ }^{3}$ Department of Molecular Genetics and Ohio State \\ Biotechnology Center, The Ohio State University, Columbus, Ohio 43210-1002 USA
}

\begin{abstract}
Neural precursor cells in Drosophila acquire their identity early during their formation. In an attempt to determine whether all neural precursors share a set of genetic machinery, perhaps to control properties of differentiation common to all neurons, we used the enhancer-trap method to identify several genes (pan-neural genes) that are expressed in all neurons and/or their precursors. One of the pan-neural genes is deadpan, which encodes a helix-loop-helix protein closely related to the product of the segmentation gene hairy. The function of deadpan is essential for viability and is likely to be involved in the functional rather than the morphological differentiation of neurons.
\end{abstract}

[Key Words: deadpan; pan-neural gene; Drosophila; HLH protein; hairy gene product; neural precursor cells]

Received July 27, 1992; revised version accepted September l, 1992.

A commonly held model for neurogenesis in Drosophila proposes that neuronal cell fates are determined by a hierarchical sequence of regulatory events (for review, see Ghysen and Dambly-Chaudiere 1989; Jan and Jan 1990; Artavanis-Tsakonas and Simpson 1991; CamposOrtega and Jan 1991). As a first step toward establishing the location of neural precursors, clusters of epithelial cells (proneural clusters) are formed that are competent to give rise to neurons. Antineuralizing signals sent between initially equivalent cells in proneural clusters then determine the number and precise spacing of primary neural precursor cells. Once the location and spacing of neural precursors has been established, these cells undergo division and differentiate in a manner characteristic of their individual identity. We have used the enhancer-trap method (O'Kane and Gehring 1987; Bellen et al. 1989; Bier et al. 1989) to determine whether there are certain aspects of the developmental program that are common to all neural precursors, despite their distinct identities. In this study we show that the deadpan $(d p n)$ gene is transiently expressed in all neural precursors and discuss its function in the nervous system.

The approximate regions in which nervous tissue forms are defined by the proneural genes, including genes of the achaete-scute complex (AS-C) and the daughterless (da) gene (Villares and Cabrera 1987; Alonso and Cabrera 1988; Caudy et al. 1988b; Gonzalez et al. 1989). Loss of function of proneural genes leads to loss of neural tissue, suggesting that these genes act to define a necessary precondition for assuming neural fates. The proneural genes identified to date all encode transcription factors possessing a DNA-binding and a protein-dimerization domain that includes the helixloop-helix $(\mathrm{HLH})$ motif and a preceding sequence rich in basic residues (bHLH) (Villares and Cabrera 1987; Caudy et al. 1988b; Gonzalez et al. 1989; Murre et al. 1989a,b). Although the $d a$ gene is expressed essentially ubiquitously (H. Vaessin, unpubl.) and is required for the formation of the entire peripheral nervous system (PNS), the four related genes of the AS-C are expressed in complex overlapping patches of cells and can substitute functionally for each other in various combinations (Cabrera et al. 1987; Dambly-Chaudiere and Ghysen 1987; Romani et al. 1987, 1989; Jimenez and Campos-Ortega 1990; Skeath and Carroll 1991, 1992; Cubas et al. 1991). The expression of AS-C genes correlates in general with the location of neural precursors that depend on the function of each of these genes.

The precise spacing of neural precursors is achieved through the action of the neurogenic genes that mediate lateral inhibition among cells in proneural clusters (for review, see Artavanis-Tsakonas and Simpson 1991; Campos-Ortega and Jan 1991). Disruption of any of these genes causes all cells in proneural clusters to assume neural fates. Some neurogenic loci encode membrane proteins (Wharton et al. 1985; Kidd et al. 1986; Vaessin 
et al. 1987; Kopezynski et al. 1988; Rao et al. 1990), whereas others encode putative transcription factors (Knüst et al. 1987; Hartley et al. 1988; Klämbt et al. 1989; Smoller et al. 1990; Boulianne et al. 1991). The existence of neurogenic genes encoding membrane proteins is consistent with a role in mediating the cell-cell interactions involved in lateral inhibition. An important consequence of these cell-cell interactions is the activation of genes from the Enhancer of split [E(spl)] complex in cells assuming epidermal fates, including several genes encoding closely related bHLH proteins (Klämbt et al. 1989).

Although much is already known about how the location and the spacing of neural precursors are accomplished (i.e., through the formation of proneural clusters and subsequent lateral inhibitory interactions), little is known about how this information converges to create a neural precursor cell. Given that different neural precursors acquire their identity by the action of different genes such as cut, pox-neural, and single-minded (Bodmer et al. 1987; Blochlinger et al. 1988; Nambu et al. 1991; Dambly-Chaudiere et al. 1992) and that the formation of different neural precursors depends on the activity of different upstream regulators (Dambly-Chaudiere and Ghysen 1987), it is not obvious a priori that all primary neural precursors need to share any common properties. In addition, the distinct identities of different neural precursors are manifested early on by their patterns of division (Doe and Goodman 1985; Bodmer et al. 1989). For example, central nervous system (CNS) neuroblasts divide according to a stem cell type of lineage in which all final progeny are neurons, whereas distinct lineages for the PNS external sensory organs and chordotonal (stretch receptor) organs yield one or a few neurons as well as support cells. To analyze early events directing nervous system formation, we asked whether genes exist that are expressed in all primary neural precursors and, if so, whether these genes control aspects of neural differentiation common to all neural precursors or their progeny. To simplify discussion of this group of genes we introduce the term pan-neural. We define a pan-neural gene as one that is expressed during some stage of neurogenesis (i.e., from the formation of primary neural precursors to the formation and differentiation of neurons) in all neural cells but not in epidermal cells.

We used the enhancer trap P element, P-lacW (Bier et al. 1989), to screen $\sim 4000$ independent P-lacW insertion lines and identified several pan-neural genes in this collection. Some correspond to known genes such as the elav gene, which is expressed postmitotically in neurons (Bier et al. 1988, 1989; Robinow and White 1988a,b); the prospero gene (Doe et al. 1991; Vaessin et al. 1991), which is expressed in secondary neural precursor cells; and the cyclin $A$ (Lehner and O'Farrell 1989), and scabrous genes (Mlodzik et al., 1990), which are expressed early during neurogenesis in primary neural precursor cells. Other pan-neural genes, such as $d p n$ (described in this paper), are newly identified genes. We report here that $d p n$ encodes a HLH protein that shows sequence similarity with the Drosophila hairy gene product. $d p n$ is expressed in primary neural precursors as soon as they form, and loss of $d p n$ function results in weak motor activities, lethargic behavior, and death. Ectopic expression of $d p n$ causes elimination of sensory bristles in flies with reduced AS-C activities, suggesting a negative interaction between $d p n$ and genes of the AS-C complex. Similar negative interactions have been described in sex determination; whereas scute functions as a numerator, $d p n$ acts as a denominator in the determination of the $\mathrm{X}$-chromosome to autosome ratio (Younger-Shepherd et al. 1992).

\section{Results}

\section{dpn, an essential pan-neural gene}

The $d p n$ gene is disrupted by a P-lacW insertion at $44 \mathrm{C}$ on the polytene chromosome, and the resulting recessive lethality is not complemented by a small deficiency, $D f(2 L) 193 A$. The lethality is the result of to the P-lacW insertion, as we have obtained viable revertants in which the P-lacW element has been excised by remobilization. We refer to this essential gene as $d p n$ because it has a pan-neural expression pattern and a lethal mutant phenotype. The mutation due to the P-lacW insertion, $d p n^{1}$, is likely to be a null mutation as it eliminates both detectable transcript and protein product (see below). Mutants homozygous for $d p n^{1}$ die at various stages of development. Under favorable conditions a few percent of the homozygotes survive to young adulthood. The $d p n^{1}$ mutant larvae are weak; many pupate in the food rather than crawl up the wall to pupate as do wild-type larvae. The rare homozygous $d p n^{1}$ mutant flies have drooped wings, are extremely sluggish, and do not show any spontaneous motor activities. Most of these mutant flies die within a few days after eclosure. In spite of the severe behavioral defects, homozygous $d p n^{1}$, homozygous $D f(2 L) 193 A$, and trans-heterozygous $d p n^{1} / D f(2 L) 193 A$ embryos do not exhibit any obvious consistent morphological abnormalities when examined with a variety of tissue-specific markers, including the following antibodies: mAb44C11 (a neuronal nuclear antigen), antiHunchback (expressed in neuroblasts), anti- horseradish peroxidase (HRP) (a neuronal membrane antigen), antiCut (a nuclear protein expressed in external sensory organ precursors), mAb22C10 (a cytoplasmic PNS antigen), anti-Sna (expressed in all neural precursor cells and neurons), anti-Eve (expressed in a pair-rule pattern and then in a subset of neurons), anti-Engrailed (expressed in segmental stripes and then in a subset of neurons), and mAb6D5 (a muscle antigen). Thus, it is likely that complete lack of zygotic $d p n$ function affects the function but not the gross morphology of the nervous system.

\section{The dpn transcription unit}

Genomic DNA flanking the $d p n^{1}$ P-lacW insertion site was isolated by plasmid rescue (Fig. $1 \mathrm{~A}_{\text {; }}$ see also Materials and methods) and used as a probe for Northern blot 

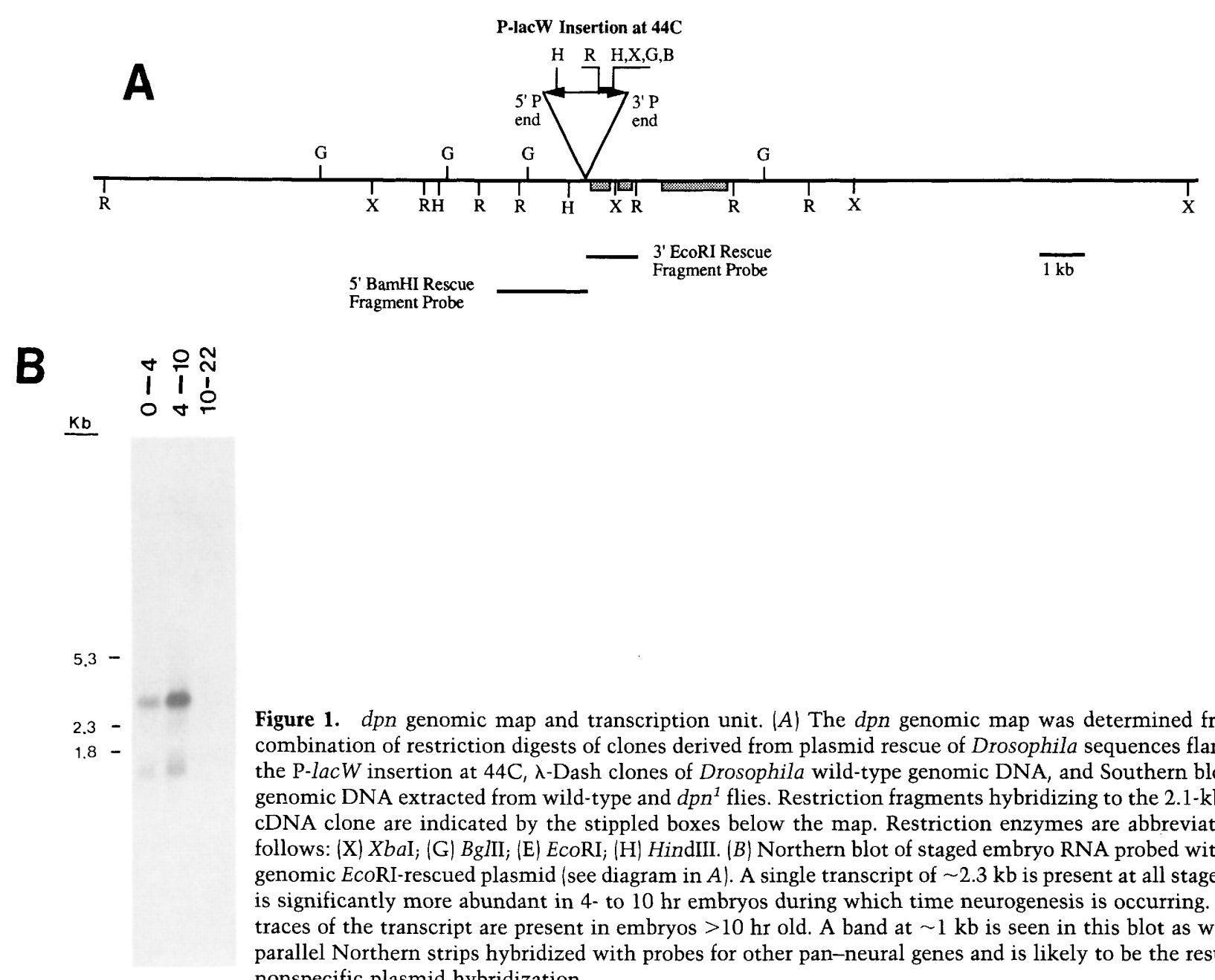

Figure 1. dpn genomic map and transcription unit. (A) The dpn genomic map was determined from a combination of restriction digests of clones derived from plasmid rescue of Drosophila sequences flanking the P-lacW insertion at 44C, $\lambda$-Dash clones of Drosophila wild-type genomic DNA, and Southern blots of genomic DNA extracted from wild-type and $d p n^{1}$ flies. Restriction fragments hybridizing to the $2.1-\mathrm{kb} d p n$ cDNA clone are indicated by the stippled boxes below the map. Restriction enzymes are abbreviated as follows: (X) XbaI; (G) BgIII; (E) EcoRI; (H) HindIII. (B) Northern blot of staged embryo RNA probed with the genomic EcoRI-rescued plasmid (see diagram in $A$ ). A single transcript of $\sim 2.3 \mathrm{~kb}$ is present at all stages but is significantly more abundant in 4- to $10 \mathrm{hr}$ embryos during which time neurogenesis is occurring. Only traces of the transcript are present in embryos $>10 \mathrm{hr}$ old. A band at $\sim 1 \mathrm{~kb}$ is seen in this blot as well as parallel Northern strips hybridized with probes for other pan-neural genes and is likely to be the result of nonspecific plasmid hybridization.

analysis of poly $(\mathrm{A})^{+}$RNA from staged embryos (Fig. 1B). Only one transcript of $2.3 \mathrm{~kb}$ was detected in embryos of $0-4 \mathrm{hr}$ and 4-10 $\mathrm{hr}$ (embryogenesis takes $22 \mathrm{hr}$ at room temperature). Ten cDNA clones corresponding to this transcript were isolated, and the two longest cDNA clones were further characterized. A digoxigenin-labeled probe synthesized from one of these clones hybridized to mRNA in all neural precursors in the embryonic PNS and CNS, revealing a pattern similar to the lacZ expression pattern due to the $d p n^{1}$ P-lacW insertion. The $d p n^{1}$ mutant embryos showed no expression of this mRNA, as revealed by in situ hybridization to whole-mount embryos (not shown). Consistent with these in situ results, antibodies raised against a Dpn fusion protein revealed staining of all neural precursors in wild-type but not in $d p n^{1}$ mutant embryos (not shown). Taken together, these results strongly indicate that the $2.3-\mathrm{kb}$ transcript corresponds to the $d p n$ gene.

\section{Embryonic expression patterns of the dpn transcript and protein product}

Zygotic expression of $d p n$ RNA is first detected early during nuclear cycle 12 at low levels throughout the em- bryo, with the exception of the pole cells at the posterior end. This broad expression peaks near the end of nuclear cycle 12 and then fades after the completion of nuclear division cycle 13, first in anterior regions leaving a transient gap gene-like pattern (Younger-Shepherd et al. 1992). dpn transcripts then reappear during the middle of cycle 13 in a pattern of eight stripes of cells (Fig. 2B) (at $\sim 3 \mathrm{hr}$ of embryogenesis). dpn transcripts are concentrated in the apical region of expressing cells (Fig. 2B), as are the transcripts of several pair-rule genes (Davis and Ish-Horowicz 1992). dpn stripes overlap with corresponding hairy stripes, which extend more posteriorly (Ingham et al. 1985b; Carroll et al. 1988), as determined by double labeling with an anti-Engrailed antiserum (Fig. $3 \mathrm{~A}, \mathrm{~B} \mid$, as well as localization of both hairy transcripts and Dpn protein in the same embryos (not shown). The most anterior $d p n$ stripe corresponds to the most anterior full hairy stripe and the most posterior $d p n$ stripe overlaps a weak hairy stripe in the hindgut primordia (see diagram in Fig. 3D). The order of appearance of $d p n$ and hairy stripes are different, however (see Fig. 2 legend). The pair-rule expression of $d p n$ RNA and protein begins to fade rapidly as gastrulation commences and is almost entirely gone as the germ band begins to elongate. 
Figure 2. Expression of $d p n$ transcripts and protein. Embryos are all oriented with anterior to the left and dorsal up unless otherwise indicated. $(A)$ Dpn protein at approximately preblastoderm cycle 12 is expressed in all nuclei. $(B)$ A sagittal view of $d p n$ transcripts expressed in a pattern of eight stripes during middle to late cycle 13 $\left(3^{1 / 2}-4 \mathrm{hr}\right.$ of development). Note that transcripts are concentrated near the apical surface (arrow), as has been observed for several pair-rule gene transcripts (Davis and Ish-Horowicz, 1992). The order of appearance of $d p n$ stripes is $5,7+2,3+4,1$, 8 , and 6 . This differs from the reported order of hairy stripe appearance, which is 1 , $2+3,4,7,5$, and 6 . (For determination of the register of $d p n$ stripes with respect to engrailed-expressing cells, see Fig. 3.) (C) A ventral view of $d p n$ transcripts in neuroectodermal patches from which the innermost and outermost rows of CNS neuroblasts will form before neuroblast segregation at $\sim 5 \frac{1 / 2}{\mathrm{hr}}$ of development. Expression in neuroectodermal patches is not observed, however, in all regions giving rise to neuroblasts (e.g., neuroblasts in row 2). In very good staining preparations Dpn protein can also be observed at low levels in similar neuroectodermal patches. $(D)$ A ventral view of $d p n$ transcripts in the
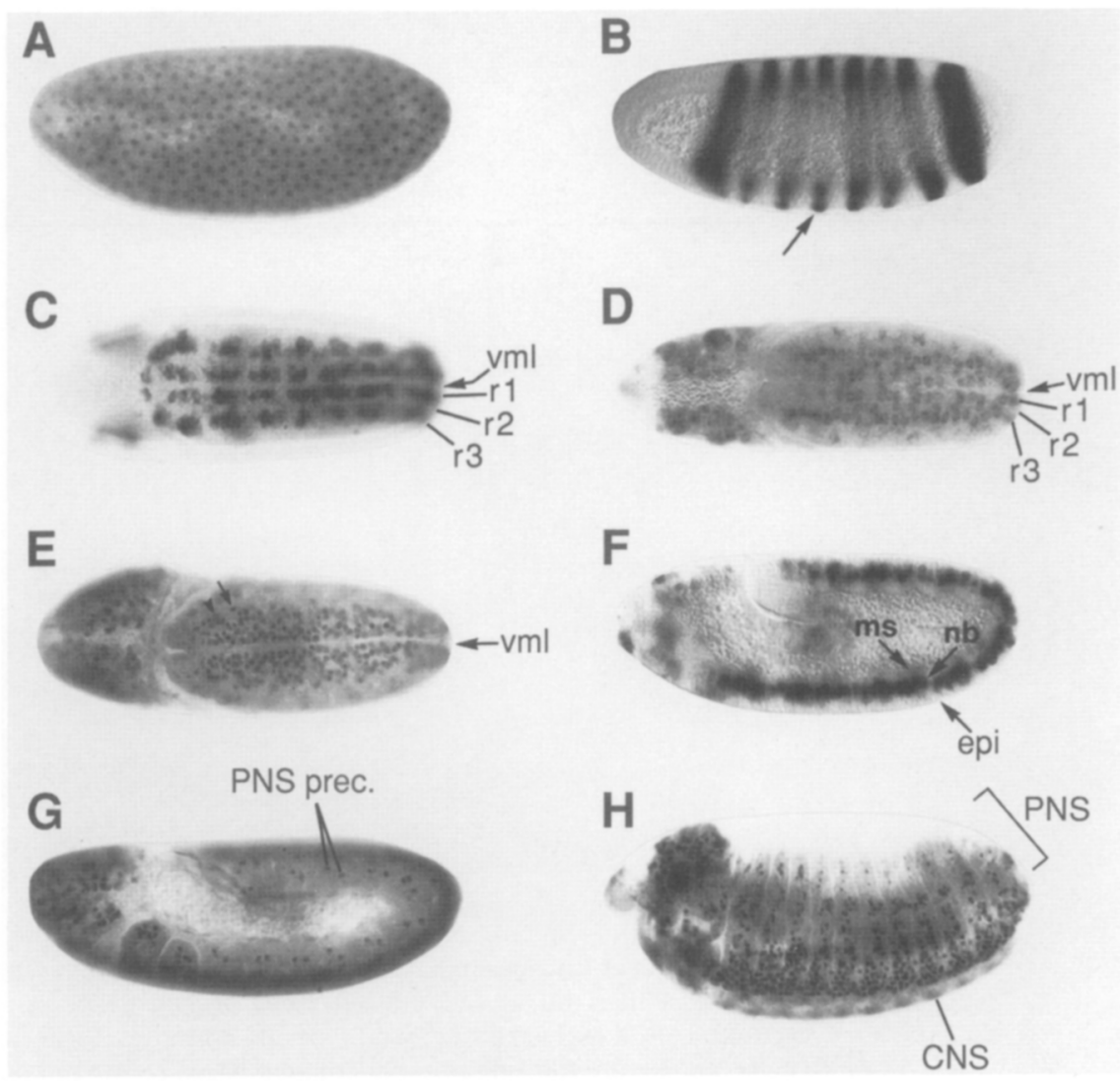
first wave of neuroblasts at $\sim 6 \mathrm{hr}$ of development. At the end of the first wave of neuroblast segregation, continuous rows of neuroblasts (four per hemisegment) are visible in row 1 (the innermost row) and row 3 (the outermost row) and in one neuroblast per segment in row 2. (E) A ventral view of a $61 / 2-\mathrm{hr}-\mathrm{old}$ embryo stained for Dpn protein showing that Dpn expression is limited to the neuroblast cell layer. Dpn is nuclear during the first wave of neuroblast segregation, but later it can also be found throughout the cell including the cytoplasm in some cells (arrowhead) as well as being strictly localized in the nucleus in other cells (arrow). dpn transcripts are also limited to neuroblasts as soon as they begin to segregate from the neuroectoderm. $(F)$ A sagittal view of $d p n$ RNA expression when all neuroblasts have segregated $(61 / 2-7 \mathrm{hr}$ of development). dpn transcripts and Dpn protein are not observed in ganglion mother cells of the CNS after neuroblast divisions, suggesting that both $d p n$ RNA and protein are very labile. $(G)$ A lateral view of Dpn protein expression in sensory organ precursor cells in the PNS. $d p n$ transcripts are transiently expressed in neuroectodermal patches before the segregation of the first PNS precursors. Subsequently, $d p n$ transcripts and protein are found only in primary neural precursor cells. $d p n$ expression is not observed in secondary PNS precursor cells after division of primary sensory organ precursor cells. $(H)$ Lateral view of Dpn protein expression in neurons of the PNS $(\sim 10 \mathrm{hr}$ of development). Dpn is also expressed in CNS neurons at this time. Dpn is likely to be expressed briefly in most neurons as lacZ expression derived from lacZ-dpn promoter fusions labels all PNS neurons (J. Emery and E. Bier, unpubl.). Although Dpn expression is transient in most neurons, it is maintained in a small subset of the CNS neurons for several hours longer (not shown). Abbreviations in this and the following figures: (A) Abdominal segments; (cf) cephalic furrow; (ect) ectoderm; (G) gnathal segments; (ms) mesoderm; (nb) neuroblast; (PNS prec.) primary sensory organ precursor cell; (r1, r2, r3) rows 1,2 , and 3, respectively, of first wave neuroblasts; (T) thoracic segments; (vml) ventral midline.

Expression of the most posterior $d p n$ stripe is maintained for the longest period but is gone before full germband extension. We should note here that $d p n^{1}$ mutant embryos did not show any detectable abnormality in the segmentation pattern.

$d p n$ transcripts are expressed briefly in patches of neuroectodermal cells just preceding the first wave of neuroblast segregation in the CNS (Fig. 2C). This expression rapidly becomes confined to the neuroblasts before their delamination (Fig. 2D). The Dpn protein follows a similar course of neural expression but is expressed at very low levels in the neuroectodermal patches before neuroblast formation. By $61 / 2-7$ hr of development all neuro- blasts have segregated and express Dpn (Fig. 2E,F). The same pattern of brief $d p n$ transcription in patches of ectodermal cells followed by strong expression of mRNA and protein in sensory organ precursor cells is observed in the PNS (Fig. 2G). The expression of $d p n$ RNA and protein in primary neural precursors disappears soon after they divide. $d p n$ is expressed transiently again at a later stage of nervous system development in the PNS and $\mathrm{CNS}$ as neurons begin to differentiate (Fig. $2 \mathrm{H}$ ), suggesting that $d p n$ may act during two distinct phases of neuronal development.

It is clear from antibody staining that Dpn is a nuclear protein, although some cells also exhibit cytoplasmic 

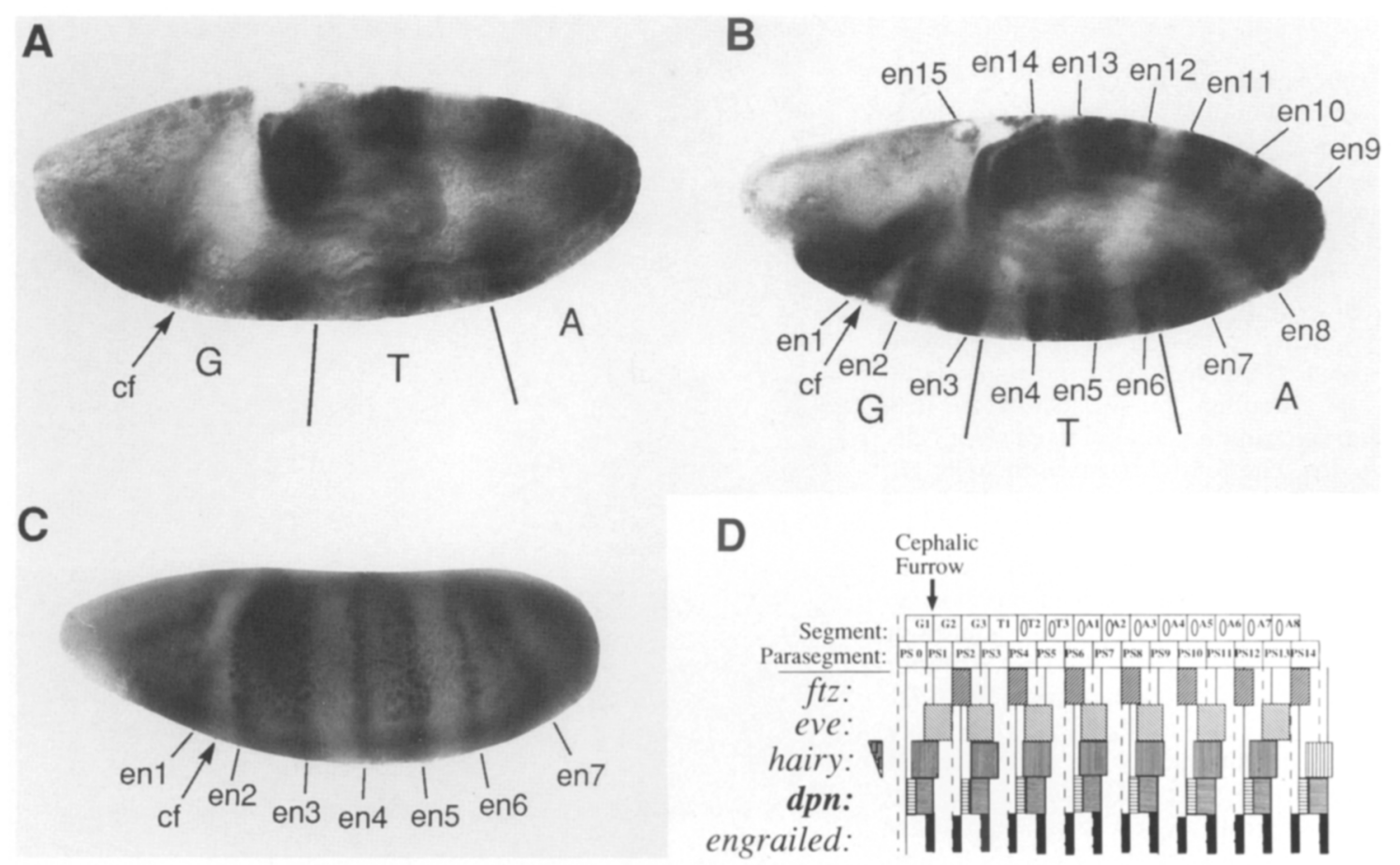

Figure 3. Register of $d p n$ stripes relative to engrailed (en) stripes. $(A)$ Sagittal view of eight stripes of lac $Z$ expression derived from the $d p n^{1} \mathrm{P}-\mathrm{lac} W$ insertion in germ-band-extended embryos (5-hr embryos). Although $d p n$ transcripts and protein have disappeared by this time, $\beta$-galactosidase (visualized with an anti- $\beta$-galactosidase antibody) is still present, presumably owing to greater RNA and protein stability. $(B)$ lac $Z$ expression (derived from the $d p n^{1}$ P-lacW insertion) plus engrailed (en) expression (visualized with the monoclonal antibody mAb4D9| in germ-band-extended $d p n^{1}$ embryos. The segmentally repeated row of darkly stained cells expressing engrailed are posterior compartment cells (labeled en1-en15). The more lightly stained cells lying between every other en stripe are those expressing lac $Z$. (C) Expression of lac $Z$ and $e n$ in 4-41/2-hr embryos. At all stages the most posterior $d p n$-expressing cell in each stripe coincides with an en-expressing cell. At the early time shown in $C$ lacZ is expressed in all cells between the en stripes. At the later stage, illustrated in $B$, however, lac $Z$ expression has faded from the most anterior cells in each stripe so that a gap is visible between the most anterior lacZ-expressing cell and the next (anterior) en-expressing cell. $(D)$ Schematic representation of $d p n$ stripe relative to expression of known pair-rule genes. Lightly stippled cells are those that lose dpn expression first. The relative frames of expression of fushi tarazu (ftz), even skipped (eve), and hairy are drawn relative to parasegment boundaries according to the data of Carroll et. al. (1988).

staining (Fig. 2E). The very first wave of neuroblast expression, however, seems to be restricted to the nucleus. Perhaps subsequent cellular events lead to a phase of less strict localization. The dynamic expression pattern suggests that $d p n$ transcripts and Dpn protein turn over rapidly. With the exception of the nuclear staining before cellularization (Fig. 2A), the antibody staining is eliminated in embryos homozygous for $d p n^{1}$ or Df(2L)193A. Whether the nuclear staining at the nuclear cleavage stages represents maternal contributions or background staining remains to be determined.

The pattern of lacZ expression derived from the $d p n^{1}$ P-lacW insertion corresponds precisely to that of the $d p n$ gene itself at all stages mentioned above (data not shown). The only difference in these patterns is that $l a c Z$ expression is maintained for longer periods of time, presumably because lacZ RNA and protein are more stable than $d p n$ transcripts and protein.

In summary, the expression patterns of $d p n$ during embryogenesis include three components. The very early expression is consistent with the functional role of $d p n$ in sex determination (Younger-Shepherd et al. 1992), and the subsequent transient, pair-rule pattern resembles that of hairy. The Dpn protein is then expressed in primary neural precursors and in neurons as they begin to differentiate. This latter pattern differs drastically from the hairy expression pattern and is likely to be responsible for the phenotype of lethargy and lethality in homozygous $d p n$ mutants.

\section{dpn expression in imaginal tissue}

We examined $d p n$ expression in the larval CNS and the imaginal discs to determine whether the later expression patterns of $d p n$ were also pan-neural or resembled the hairy expression pattern. Comparison of the $d p n$ and hairy patterns in discs is of particular interest because of the conspicuous absence of hairy expression in neural precursors and neurons. $d p n$ is expressed in neuroblasts of the larval CNS and in precursors of sensory neurons in the imaginal disc (Fig. 4). dpn expression is restricted to the primary neural precursor cell. This can be seen most easily in Figure 4, B and D, in which CNS neuroblasts are labeled with the anti-Dpn antiserum, whereas the gan- 
Figure 4. $d p n$ expression in larval CNS and imaginal discs. Expression of Dpn protein $(B, D)$ is compared with $l a c Z$ expression owing to the $d p n^{1}$ P-lacW insertion $(A, C)$ in larval CNS $(A, B, C, D)$. At lower magnification $(A, B)$, expression in the larval CNS is evident in neural precursors at the ventral side of the thoracic ganglia (Truman and Bate $1988)$, as well as in the larval brain $(\mathrm{Br})$. Neurons in the eye disc $\langle E\rangle$ also express $d p n$. $|A|$ At the lateral view, the thoracic ganglia are to the right of the brain and the abdominal ganglia (below the thoracic ganglia) contain no neural precursors or cells that express $d p n$. The ventral side is to the right. $|B|$ A dorsal view of the thoracic and ventral ganglia and the two brain hemispheres $(\mathrm{Br})$ on either side. The disc is connected to the brain by the eye stalk. The neuroblasts on the ventral side of the thoracic ganglia can be seen through the entire thickness of the ganglia, owing to the staining for Dpn. Anterior is up for both $A$ and $B$. At high magnification $(C, D)$, Dpn protein $(C)$ is clearly localized to the primary neuronal precursor, the neuroblast $(\mathrm{NB})$, whereas the long-lived lac $Z$ product $(D)$ persists in the secondary neuronal precursor, the ganglion mother cell (GMC), and neurons derived from the neuroblast. Brackets indicate groups of cells, each derived from a single neuroblast. In the leg disc, shown at two different focal planes $(E, F), d p n$ is expressed in chordotonal organ (Cho) precursors and other sensory organ precursors (arrows), as well as stripes of epidermal cells.

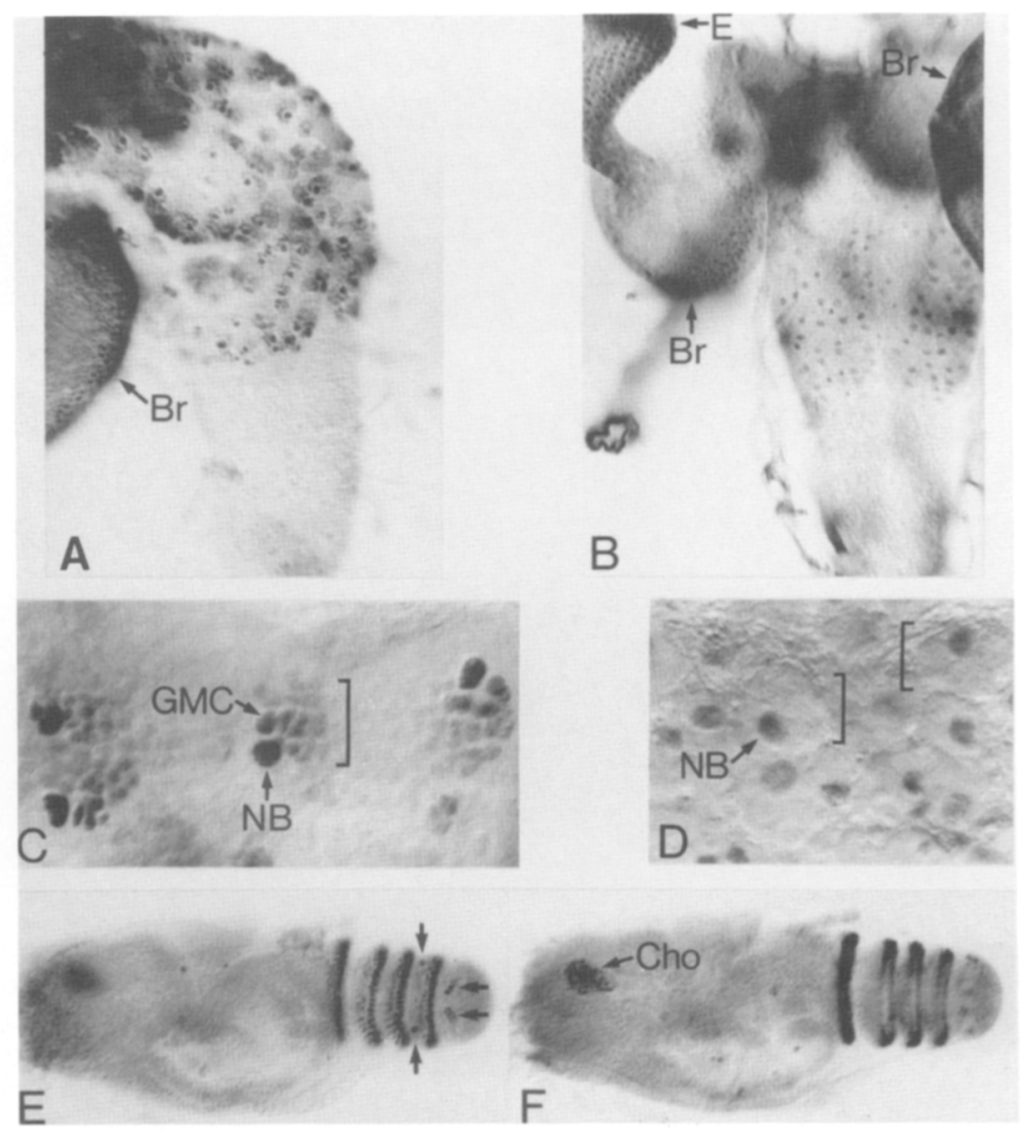

glion mother cells and their neuronal progeny do not stain. In contrast, the bacterial $\beta$-galactosidase protein encoded by the lacZ gene in P-lacW has a much longer lifetime; therefore, lac $Z$ expression in heterozygous $d p n^{1}$ larvae led to $l a c Z$ staining of all CNS neuroblasts as well as their progeny, the ganglion mother cells, and the neurons (Fig. 4C).

In leg imaginal discs $d p n$ is also expressed in additional non-neuronal cells. Thus, $d p n$ is expressed in stripes at the distal edge of each leg segment primordium (Fig. 4E,F). Expression in these cells is very similar to the pattern of hairy expression in imaginal discs (Carroll and Whyte 1989). The major difference between $d p n$ and hairy expression in the leg imaginal discs is that hairy is excluded from neural precursor cells.

\section{dpn expression in embryos lacking proneural and neurogenic gene functions}

The expression of $\mathrm{Dpn}$ in neuroblasts serves as a criterion for neuroblast differentiation, in addition to the morphological criterion of neuroblast enlargement and delamination. This has provided a tool to investigate the function of proneural genes (e.g., da and AS-C). In embryos lacking zygotic da function, the PNS is missing completely and the CNS is greatly reduced (Caudy et al. 1988a). As expected from the absence of the PNS, neural precursors for the PNS do not form in $d a$ mutants /Caudy et al. 1988a). In contrast, many of the CNS neuroblasts delaminate in a roughly normal pattern (Jimenez and Campos-Ortega 1990), even though far fewer than the normal number of final neurons form (Caudy et al. 1988a; Jimenez and Campos-Ortega 1990; M. Brand, pers. comm.). This suggests that either only a fraction of the neuroblasts follow their normal patterns of division or all neuroblasts behave abnormally and produce fewer neurons than normal. We found that the remaining CNS neuroblasts in $d a$ mutants did not express any detectable levels of $d p n$ RNA or protein, although the ventral midline cells in the same $d a$ mutant embryos expressed rhomboid transcripts (Fig. 5B). Thus, all neural precursors in da mutant embryos are abnormal; they do not express $d p n$ and they produce very few neurons. Although early $d p n$ expression in neuroblasts appears likely to be directly activated by $d a$, later expression of $d p n$ was found in some CNS neurons in $d a / d a$ mutant embryos, indicating that more than one mechanism controls $d p n$ expression at different developmental stages.

The CNS phenotype in embryos deficient for AS-C is similar to that in $d a$ mutant embryos; fewer neuroblasts are formed than in wild-type embryos and far fewer than normal number of CNS neurons are found later during neurogenesis (Jimenez and Campos-Ortega 1990). This similarity in the CNS phenotype no longer holds when the $d p n$ expression patterns are examined. In contrast to 


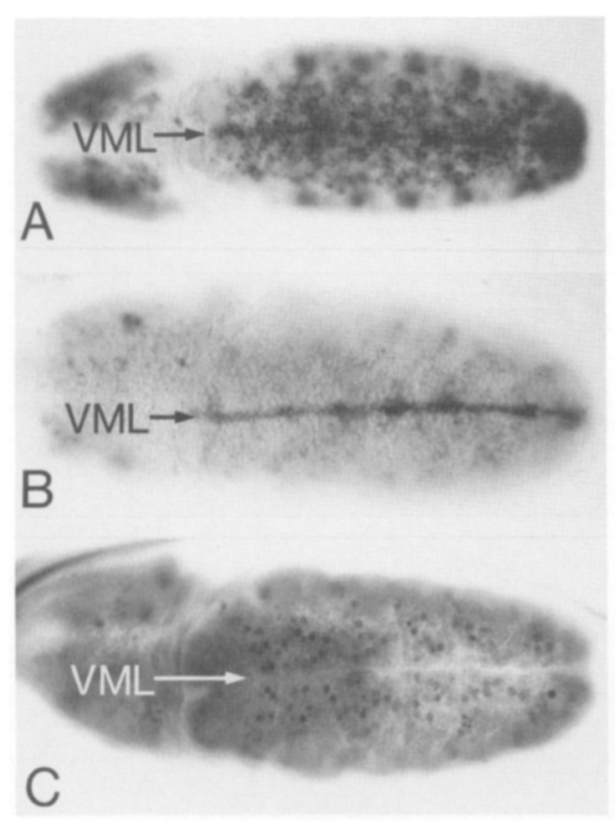

Figure 5. Expression of the $d p n$ gene in $d a^{-}$and $A S-C^{-} m u-$ tants. (A) Pattern of RNA expression in a wild-type $61 / 2-\mathrm{hr}$ embryo hybridized simultaneously with $d p n$ and rhomboid digoxigenin-labeled DNA probes. Neuroblasts normally express $d p n$, whereas midline cells express rhomboid (Bier et. al. 1990) but not $d p n$ (see Fig. 2E) at this stage. $(B)$ Pattern of RNA expression in a $d a / d a$ mutant embryo $(61 / 2-\mathrm{hr}$ of development) hybridized simultaneously with $d p n$ and rhomboid digoxigenin-labeled probes. No expression in neuroblasts is detectable. The absence of $d p n$ expression is not th eresult of failure of the hybridization procedure as rhomboid is expressed at normal levels in midline cells of this embryo. (C) Dpn protein expression in embryos in which the AS-C genes are deleted owing to the $s c^{B 57}$ deficiency. There are many fewer Dpn-expressing cells in the $s c^{B 57}$ embryo than in wild-type embryos (cf. Fig. 2E); however, several neural precursor cells per hemisegment do stain with roughly normal intensity. Thus, in contrast to da/da mutants, Dpn is expressed at normal levels in a reduced number of neural precursor cells. Because analysis of neurogenesis in embryos lacking AS-C genes indicates that perhaps $<50 \%$ of the normal number of neuroblasts form (Jimenez and Campos-Ortega 1990), it is possible that all neuroblasts remaining in $s c^{B 57}$ mutants express $d p n$ as do their normal counterparts. (VML) Ventral midline.

homozygous da mutants, embryos homozygous for the $s c^{B 57}$ deletion $\left(s c^{B 57}\right.$ eliminates all known AS-C transcription units) express normal levels of Dpn in a reduced number of neuroblasts. The Dpn-expressing neuroblasts in $s c^{B 57}$ mutants are most numerous near the midline during the first wave of neuroblast formation and, in general, are observed in groups of cells that are mirror symmetric with respect to the midline (Fig. 5C). Thus, although $d a$ is required for expression of detectable levels of Dpn in all neuroblasts, AS-C function appears to be dispensable for the formation of a subset of CNS neuroblasts that express $d p n$.

The very early expression of $d p n$ in primary neural precursors also offers an opportunity to examine the effects of neurogenic mutations. Embryos homozygous for the neurogenic mutations $E(s p 1)$, Notch, Delta, and neuralized form an excess of Dpn-expressing cells /data not shown|. This hyperplasia of the nervous system is evident when the first wave of neuroblasts delaminate from the neuroectoderm, consistent with the early actions expected of neurogenic genes in the determination of neural precursors.

\section{The dpn gene encodes a protein with a bHLH domain}

The two longest $d p n$ cDNA clones were sequenced. The $2.1-\mathrm{kb}$ clone is nearly full length and includes a complete open reading frame, whereas the $2.2-\mathrm{kb}$ clone is likely to represent a partially spliced version of the gene. The predicted protein encoded by the $2.1-\mathrm{kb}$ cDNA (Dpn) contains 435 amino acids (Fig. 6). Consistent with its nuclear localization, the Dpn protein contains a HLH motif and a preceding basic residue-rich sequence (bHLH) near the amino terminus. bHLH domains in proteins such as E12/E47, Da, and MyoD have been shown to bind to specific DNA sequences (Murre et al. 1989a,b). Among the known bHLH proteins, the Dpn bHLH domain shows the highest degree of sequence similarity with the product of the Drosophila segmentation gene hairy (Hairy) (there is $84 \%$ amino acid identity and $92 \%$ similarity permitting only the most conservative changes) over 61 amino acids in the bHLH region (Fig. 7A). It appears likely that $d p n$ and hairy arose from a common ancestral gene because the additional sequence that is present in the $2.2 \mathrm{~kb} d p n$ cDNA, but not in the $2.1-\mathrm{kb}$ $d p n$ cDNA, contains the appropriate consensus sequences for mRNA splicing, suggesting that it is an intron of the $d p n$ gene; and the location of this putative splice site corresponds precisely to an intron-exon boundary in the hairy gene. The Dpn and Hairy bHLH domains are also similar to the bHLH domains of the highly related proteins of the $E(s p l)$ complex than to other known bHLH proteins. For example, the bHLH domains of Dpn, Hairy, and the gene products of the $E$ (spl) complex all have a characteristic proline residue in the basic domain.

Dpn, Hairy, and the gene products of the $E(s p l)$ complex also share structural features outside the bHLH domain (Fig. 7). In the 53-amino-acid residues immediately carboxyl to the bHLH domain, Dpn and Hairy share $42 \%$ amino acid identity. After this region, both proteins are rich in proline, serine, and threonine residues, although the sequences do not align. The bHLH proteins encoded in the $\mathrm{E}$ (spl) complex also show sequence similarity to Dpn and Hairy in these carboxyl domains, although the degree of similarity is less marked. Finally, proteins in this group all possess the same four carboxy-terminal amino acids WRPW. This last feature is not found in any other known bHLH proteins.

\section{dpn mutations interact genetically with known genes required for neurogenesis}

Genes acting in common developmental pathways often exhibit dosage sensitive interactions. In such cases, mu- 


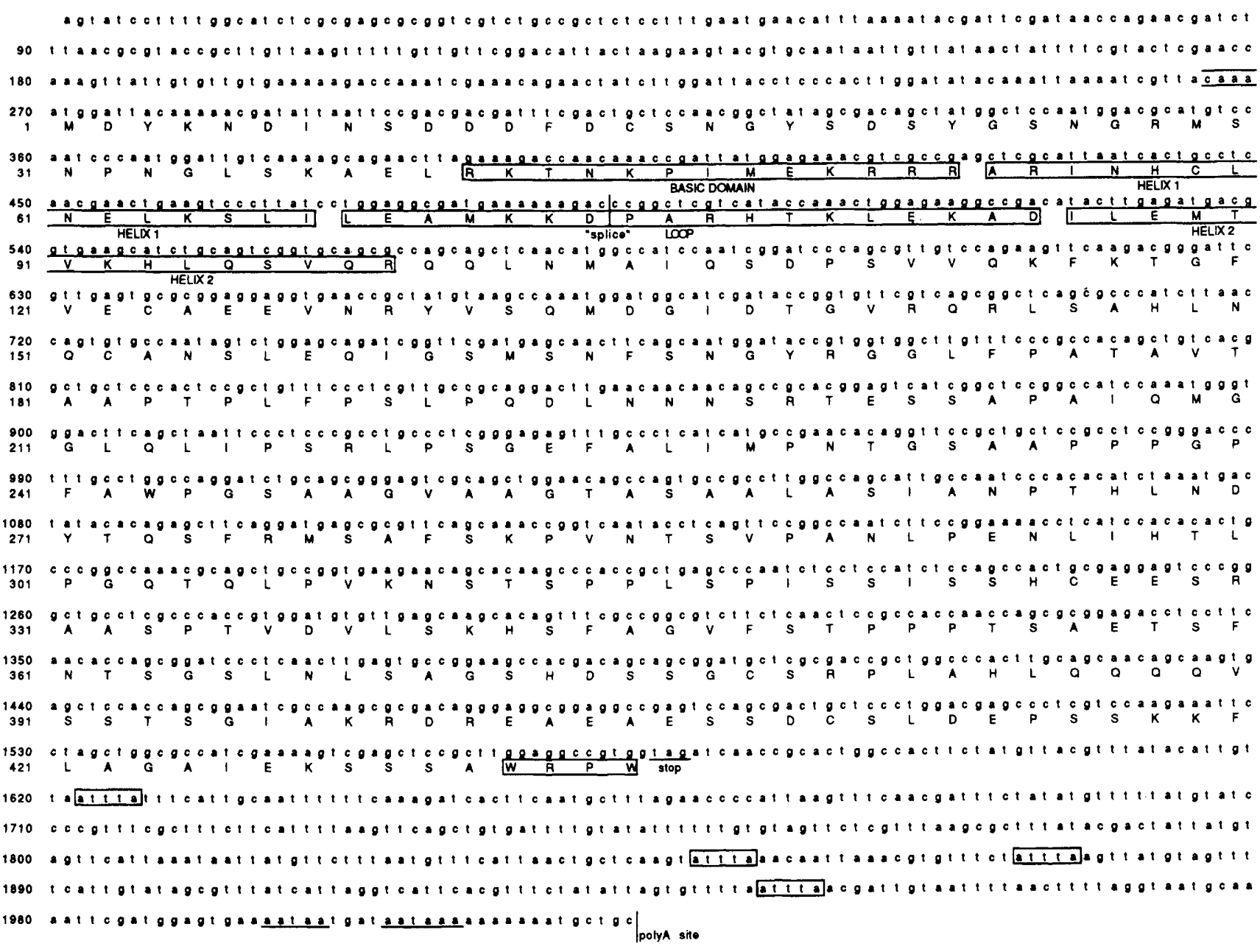

Figure 6. Sequence analysis of $d p n$ cDNA clones. The sequence of the $2.1-\mathrm{kb}\left[2023 \mathrm{bp}\right.$ long, not including the poly $\left.(\mathrm{A})^{+} \mathrm{tail}\right]$ and $2.2-\mathrm{kb}$ (2223 bp) dpn cDNAs were determined by single-stranded dideoxy sequencing of both strands of each clone. The 2.1-kb cDNA contains a single open reading frame encoding a predicted protein (Dpn) of 435 amino acids (represented by the standard single-letter code). The predicted Dpn protein contains a bHLH domain near the amino terminus, followed by a region rich in proline, serine, and threonine, and terminating in the tetrapeptide WRPW. The sequence of the $2.2-\mathrm{kb}$ cDNA is identical to the $2.1-\mathrm{kb}$ cDNA after nucleotide 492 . The sequence immediately preceding nucleotide 492 in the $2.2-\mathrm{kb}$ cDNA is ttccttcgtcttctatacttttag/ccg, which matches well with the consensus for a $3^{\prime}$ splice acceptor site: $\left.(\mathrm{t} / \mathrm{c}) \mathrm{n} \geqslant 12 X \mid \mathrm{t} / \mathrm{c}\right) \mathrm{ag} / X X X$. This site is marked as splice. The likelihood that the $2.2-\mathrm{kb} \mathrm{cDNA}$ represents an incompletely spliced mRNA is strengthened by the fact that there is a splice site at precisely the same location in the bHLH-encoding region of the hairy gene (i.e., between codons for Asp-74 and pro-75). Given that the dpn and hairy genes encode highly similar bHLH domains (see Fig. 7), are expressed in overlapping spacial patterns, and share a splice site, they probably evolved from a common ancestral gene. This view is supported further by the observation that the 9 nucleotides preceding the putative 3 ' splice site in the $d p n$ gene (highlighted in bold) are $100 \%$ conserved in the corresponding hairy gene intron. The sequence caaa that precedes the first potential methionine residue in the open reading frame matching the translation start consensus (c/a)aa(c/a) (Cavener 1987) is underlined and overlined. Four copies of sequence motif attta are underlined in the 3 '-nontranslated region of the $d p n \mathrm{cDNA}$. This sequence has been shown to lead to RNA instability (Shaw and Kamen 1986) and has also been implicated in translation control (Kruys et al. 1989). Two potential polyadenylation signals located 24 and 13 nucleotides, respectively, upstream from the polyadenylation sites used in both the $2.1-\mathrm{kb}$ and $2.2-\mathrm{kb}$ cDNAs are also underlined.

tations of two genes that are each recessive yield a visible phenotype when combined as transheterozygotes (Botas et al. 1982; Moscoso del Prado and Garcia-Bellido 1984; Vaessin et al. 1985; Bopp et al. 1986; Baumgartner et al. 1987; Brand and Campos-Ortega 1988, 1990; Dambly-Chaudiere et al. 1988; de la Concha et al. 1988; Ziemer et al. 1988; Xu et al. 1990). We have evidence for two types of genetic interactions between $d p n$ and the proneural AS-C genes, which encode bHLH proteins expressed in proneural clusters. The first genetic interaction results in lethality of more than half of the males heterozygous for the $d p n^{1}$ mutation that also carry a duplication of AS-C. This interaction appears to affect sex determination (Younger-Shepherd et al. 1992). A similar interaction between $d p n$ and AS-C can be observed in both the embryonic and the adult nervous system. We 

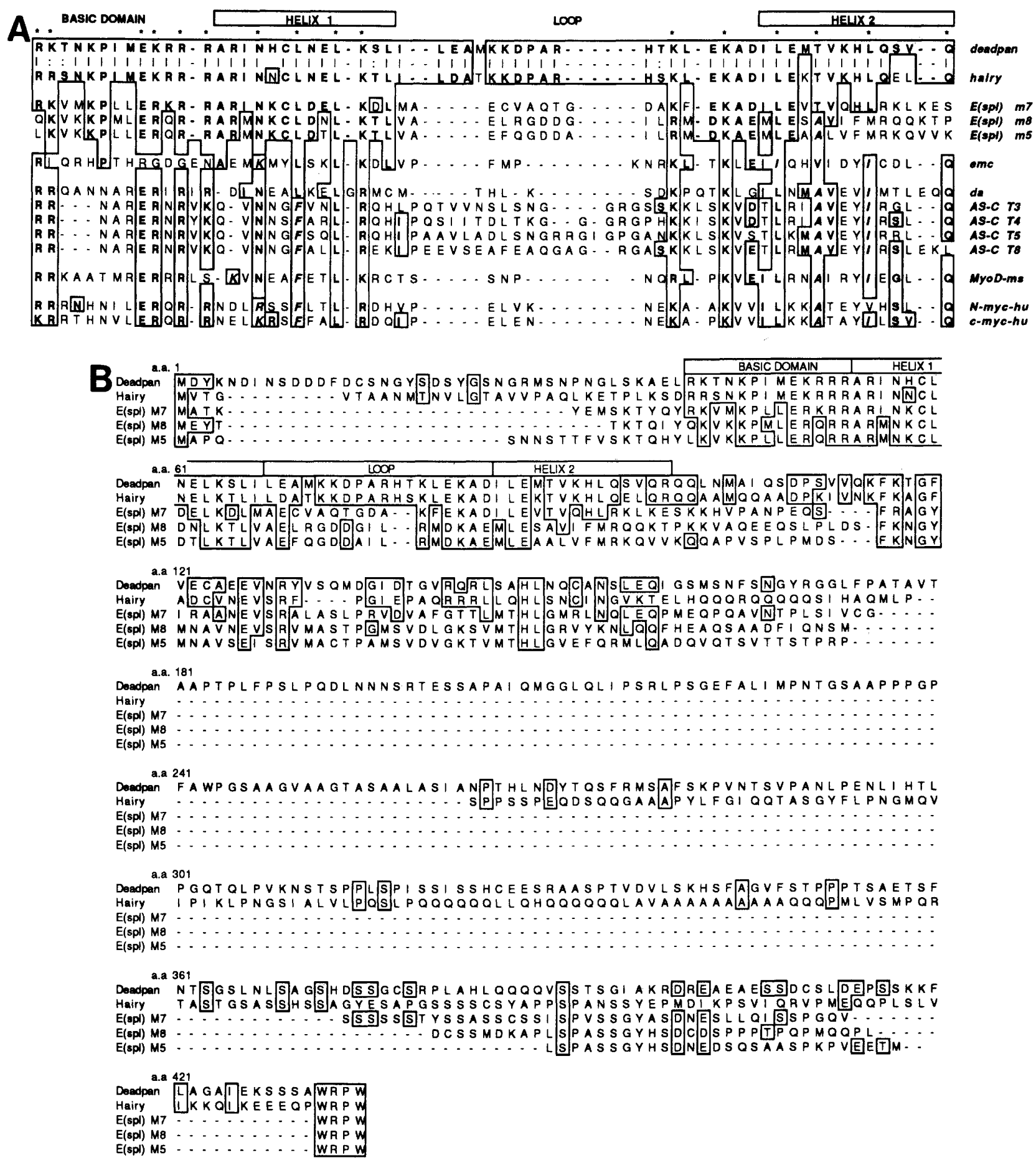

Figure 7. Alignment of Dpn and other bHLH protein sequences. (A) Alignment of the Dpn bHLH region with other bHLH domains. Vertical lines indicate amino acid identity between Dpn and Hairy bHLH sequences, and broken lines indicate highly conservative substitutions. Boxed and bold sequences are identical or highly similar (italicized) to Dpn. Asterisks $\left({ }^{\star}\right)$ denote conserved positions in the group of HLH proteins listed. HLH genes listed include Hairy (Rushlow et al. 1989); proteins encoded by E(spl) transcription units m5, m7, m8 (Klämbt et al. 1989); Extramacrochaete (emc) (Ellis et al. 1990; Garrel and Modolell 1990); Daughterless (da) (Caudy et al. 1988b); proteins encoded by AS-C genes T3 (1'sc), T4 (sc), T5 (ac), and T8 (ase) (Villares and Cabrera 1987; Gonzalez et al. 1989); mouse MyoD (MyoD-ms) (Lasser et al. 1989); and human c-myc and N-myc (Kohl et al. 1986; DePinho et al. 1987). Note that although the Dpn bHLH domain is most similar to that of Hairy, it is also more similar to E(spl) proteins in this region than to other bHLH domains. ((B) Alignment of complete Dpn, Hairy, and E/spl) protein sequences. The Dpn, Hairy, and E/spl) proteins share additional sequence similarities outside the conserved bHLH domains. In particular, there is a region of higher sequence similarity directly after the HLH domain. This region is followed by segments of differing length that are rich in the amino acids proline, serine, and threonine. These proteins also all end in the tetrapeptide WRPW. 
have inserted the protein-coding region of the $2.1-\mathrm{kb} d p n$ cDNA into the pWH1 heat shock P-element vector (Schneuwly et al. 1987) and introduced this heat shock$d p n$ (HS-dpn) construct into flies by P-element-mediated transformation (Spradling 1986). When heterozygous $s c^{B 57}$ female flies that carry one copy of this construct are heat shocked during early pupation, many of the innervated small bristles (microchaete) are missing (in some of these flies there are only four rows of microchaete instead of the normal eight rows between the large dorsocentral macrochaetes). This interaction between HS-Dpn and AS-C could reflect a normal interaction of Dpn and AS-C products or might be nonphysiological. We favor a specific interaction between $d p n$ and AS-C as similar heat shock experiments performed with a heat shock-Hairy (HS-Hairy) construct in $s c^{B 57}$ heterozygotes results mainly in the loss of dorsocentral macrochaete, whereas HS-Dpn affects mainly microchaete. These observations indicate that like hairy, $d p n$ acts in a manner antagonistic to genes of the AS-C.

\section{Discussion}

\section{Neural precursors: a tissue type with individual properties}

The existence of early pan-neural genes suggests that the diverse genetic paths by which different ectodermal cells become specified as neural precursors all converge to activate a common genetic program. Thus, although different neural precursors rely on different genes, such as cut (Bodmer et al. 1987; Blochlinger et al. 1988), and pox-neural (Dambly-Chaudiere et al. 1992), to acquire their own identity, they all express pan-neural genes. Pan-neural genes may therefore integrate the varied upstream regulatory pathways specifying different neural precursors and allow the collection of many individual neurons to differentiate as a coherent neural tissue type. The consolidation of complex early positional pattern information into a relatively small number of pan-neural genes may simplify the problem of activating functions common to all neural precursors and their neuronal progeny. In this view, pan-neural genes would function analogously to the pair-rule class of segmentation genes that transform global positional information provided by the gap genes and the maternal morphogen into regularly spaced stripes.

The functions of some pan-neural genes have been implicated from the sequence of their products. Panneural transcription factors are likely to regulate genes required for executing neural functions or to repress genes functioning in other tissues such as mesoderm or epidermis. For example, the prospero gene function is required for proper axonal outgrowth and path finding of both central and peripheral neurons (Doe et al. 1991; Vaessin et al. 1991). Whether these pan-neural regulatory factors individually control subsets of neuronal functions, such as axonogenesis and electrical excitability, or collaborate in some combination to regulate neu- ronal differentiation remains to be determined. Besides nuclear proteins potentially involved in gene regulation, as in the case of dpn and prospero (Vaessin et al. 1991), other pan-neural gene products may be involved in cellcell communication (Mlodzik et al. 1990), control of the cell cycle (Lehner and O'Farrell 1989), and RNA processing (Bier et al. 1988, 1989; Robinow and White 1988b).

\section{Possible function of the dpn gene}

$d p n$ is an essential gene, as loss of $d p n$ function results in lethality. $d p n$ does not appear to be necessary for normal morphogenesis of the nervous system, as $d p n$ mutant embryos or escaper flies do not exhibit any consistent morphological defects. One possibility is that $d p n$ regulates a subset of events in neural precursors unrelated to morphogenesis. We are currently screening through more markers specific to various subsets of the CNS, PNS, and epithelium to identify potential target genes that may be positively or negatively regulated by $D p n$. Another possibility is that other genes (perhaps encoding bHLH proteins) act in parallel with $d p n$ in neural precursors. This would not be surprising given the known examples of the overlapping function of subgroups of bHLH proteins [e.g., AS-C and $E$ (spl) complex] functioning in neurogenesis (Cabrera et al. 1987; DamblyChaudiere and Ghysen 1987; Romani et al. 1987, 1989; Jimenez and Campos-Ortega 1990; Campos-Ortega and Jan 1991). This possibility may be explored by further analyzing the interaction of $d p n$ with AS-C and possibly with genes encoding other bHLH proteins that can be isolated based on their sequence similarity to $d p n$ (E. Bier and J. Feder, unpubl.).

The bHLH motif in Dpn suggests that this nuclear protein is involved in transcription regulation. The presence of a proline residue in the basic domain of Dpn raises questions concerning the ability of Dpn to bind DNA, as a proline for alanine mutation in MyoD at a position corresponding to the neighboring residue of the proline found in Dpn, Hairy, and proteins encoded by the $E(s p l)$ complex rendered the mutant MyoD protein unable to bind to the cognate DNA sequence (Lassar et al. 1989; Davis et al. 1990). Moreover, ectopic expression of the hairy product, which also contains a proline in the basic domain and shows strong overall sequence similarity with the $d p n$ product, has been found to interfere with sex determination, presumably owing to the formation of nonfunctional heterodimers of Hairy and the AS-C T4 gene product (Parkhurst et al. 1990). The malespecific lethality caused by the negative interaction between AS-C and dpn in sex determination indicates that $d p n$ and hairy interact with AS-C genes in a similar manner (Younger-Shepherd et al. 1992). According to this view, $E(s p l)$ proteins might also act to inactivate proneural bHLH heterodimers in cells assuming epithelial fates. On the other hand, the protein encoded by the $\mathrm{m} 8$ gene of the $E(s p l)$ complex binds a specific DNA target sequence, even though it contains a proline in the basic domain (Tietze et al. 1992). Preliminary data suggest that the Dpn protein also binds DNA (H. Vaessin, unpubl.). 
How Dpn might interact with other bHLH proteins is an important question to be addressed in future studies. One possibility is that Dpn functions in neural precursor cells to turn off AS-C expression (AS-C expression in neural precursors is very transient) by interfering with the autoregulatory loop of AS-C activation, which has been demonstrated in the adult PNS (Martinez and Modolell 1991). In this model Dpn would carry out the same function in neural precursors that Hairy executes in epidermal precursors; whereas Hairy is expressed in cells surrounding the neural precursor, thereby preventing these cells from adopting the neural precursor fate by suppressing AS-C expression, Dpn is expressed in neural precursors but with sufficient delay to allow the initial steps of neurogenesis to proceed before the suppression of AS-C expression.

\section{Potential implications for the evolution of neural patterning}

Recent observations suggest that certain developmental pathways have been conserved throughout large branches of phylogeny. For example, the strong homology in sequence and expression pattern between Drosophila homeotic genes and their vertebrate counterparts suggests that positional values are likely to be specified by similar mechanisms in these organisms (Akam 1989; Malicki et al. 1990; McGinnis et al. 1990). There are also striking examples of homologous regulatory genes expressed in the same tissues throughout phylogeny. This is well documented for genes regulating myogenesis such as $M y o D$, twist, and snail (Boulay et al. 1987; Thisse et al. 1988; Hopwood et al. 1989; Michelson et al. 1990; Sargent and Bennett 1990) and is likely to be the case for genes determining neural identities, as vertebrate homologs of the proneural $A S-C$ genes are expressed in neural precursor cells (Johnson et al. 1990; Lo et al. 1991; W. Harris, unpubl.). Finally, the Drosophila emc gene, which acts to suppress neurogenesis, may be a homolog of the vertebrate Id gene (Benezra et al. 1990; Ellis et al. 1990; Garrell and Modolell 1990). It is therefore of substantial interest to determine whether Drosophila pan-neural genes have vertebrate homologs that are also expressed in pan-neural patterns.

Within a given organism, developmental strategies often share significant features. For example, pattern formation is achieved by mechanisms of progressive refinement both during neurogenesis and body axis formation in Drosophila (Ingham 1988; Ghysen and DamblyChaudiere 1989; Jan and Jan 1990). Furthermore, these genetic programs employ common genes. Thus, early in development, hairy, fushi tarazu, and even-skipped function to specify anterior-posterior positions, and rhomboid acts to establish dorsal-ventral cues (Jürgens et al. 1984; Nüsslein-Volhard et al. 1984; Ingham et al. 1985a; Mayer and Nüsslein-Volhard 1988). These same genes then function again later to assign various cell fates in the nervous system (Doe et al. 1988a,b; Rushlow et al. 1989; Bier et al. 1990). The observation that $d p n$ is expressed in a pair-rule pattern at the cellular blasto- derm stage and then again in a pan-neural pattern may represent yet another example of a gene functioning at multiple distinct stages of development. Alternatively, the $d p n$ blastoderm pattern may reflect the common ancestry shared by $d p n$ and hairy.

\section{Materials and methods}

Fly stocks

All genetic markers and chromosome balancers used are described in Lindsley and Grell (1968). The Df(2L)193A stock was kindly provided by J. Hooper.

\section{Antibody staining of embryos}

The following primary antibodies were used according to published conditions: rabbit anti- $\beta$-gal (Cappel); mAb44C11 (Bier et al. 1988); anti-Hunchback (provided by P. McDonald; see Small et al. 1991); anti-HRP (Jan and Jan 1982); anti-Cut (Blochlinger et al. 1988); mAb22C10 (Venkatesh et al. 1985); anti-Sna (Kosman et al. 1991); anti-Eve (provided by M. Frasch; see Small et al. 1991); anti-Engrailed (provided by T. Kornberg; see Patel et al. 1989); and mAb6D5 (Caudy et al. 1988a). To visualize primary antibodies we used biotinylated secondary antibodies followed by avidin D-HRP from Vectastain ABC elite kits (Vector Laboratories, PK-4001). After reacting HRP with diaminobenzidine, the samples were dehydrated in ethanol, cleared in xylene, mounted on slides with Permount (Fisher), and examined under a microscope with Nomarski optics.

\section{Production of antibodies against Dpn}

To raise antibodies against Dpn, an internal BamHI fragment (base pairs 594-1363) encoding amino acids 109-365 of the predicted Dpn protein, was cloned in the pet 3 vector (Rosenberg et al. 1987) and expressed in bacteria. This part of Dpn was chosen, because it has only limited similarity to hairy. After lysis of the bacteria, the initially insoluble fusion protein was separated from soluble bacteria proteins by centrifugation at $10,000 \mathrm{rpm}$ for $15 \mathrm{~min}$ and subsequently resolubilized in $8 \mathrm{M}$ urea, $1 \times$ PBS. Renaturation of the protein was done by stepwise dialysis against decreasing concentrations of urea $(2 \mathrm{M}$ urea increments, each step for $3 \mathrm{hr}$ at room temperature). After two additional dialysis steps against $1 \times$ PBS, the resulting soluble protein, which consisted at this stage of $>50 \%$ Dpn fusion protein, was used for immunization of two rabbits. Serum from these animals was subsequently purified in two steps. First, the serum was preabsorbed against total bacterial protein, coupled to Affigel $10+15$ (Bio-Rad) to remove the antibodies directed against bacterial proteins. Subsequently, anti-Dpn antibodies were purified by affinity purification against $D$ pn fusion protein coupled to Affigel 10 (Bio-Rad). Antibodies bound to the Dpn fusion protein were recovered by elution with $1.5 \%$ glycine $/ \mathrm{HCl}(\mathrm{pH}$ 2.3).

In situ hybridization to RNA in sections or whole-mount embryos

In situ hybridization to whole-mount embryos was done following the method of Tautz and Pfeifle (1989), using digoxigenin labeled DNA or RNA probes (Boehringer Mannheim; 1093 657). 
Plasmid rescue of genomic sequences flanking the $\mathrm{dpn}^{1} P$-lacW insertion

We used the unique EcoRI and BamHI restriction sites in P-lacW to plasmid rescue genomic DNA flanking the $3^{\prime}$ and $5^{\prime}$ sides of the P-lacW insertion at $44 \mathrm{C}$, respectively (see genomic map in Fig. 1). DNA fragments containing fly sequences from the two rescue plasmids were labeled with ${ }^{32} \mathrm{P}$ and hybridized to Southern blots of wild-type and $d p n^{1}$ DNA and Northern blots of staged embryonic RNA. Hybridization of these fragments to Southern blots of wild-type genomic DNA was consistent with the restriction map deduced from the rescued genomic DNA (data not shown).

Northern blot analysis of RNA extracted from staged embryo collections using the labeled rescued genomic fragments as probe is shown in Figure 1B. Strong hybridization to the $2.3-\mathrm{kb}$ transcript is observed in lanes corresponding to 0 - to 4- and 4- to 10-hr embryos using the genomic fragment derived from the EcoRI-rescued plasmid. This same transcript is only weakly detected in 10 - to 20 -hr embryos. No hybridization is observed to a Northern blot processed in parallel using the genomic fragment contained in the BamHI-rescued plasmid as probe, although this same probe hybridized subsequently to a genomic Southern blot (data not shown).

\section{Construction of the dpn heat shock vector}

The coding region of $d p n$ between nucleotides 266 and 1578 was amplified by the polymerase chain reaction and cloned into the SmaI site of the Bluescript plasmid modified to have the SpeI site converted to a $K p n I$ site (the EcoRV site was also converted to a $B g l I I$ site for other purposes). The $d p n$ insert was removed from this plasmid with KpnI and subcloned into the P-element transformation vector pWHI (Schnewly et al. 1987), cut with $K p n I$ in the $5^{\prime}$ to $3^{\prime}$ direction relative to the HSP70 promoter. This construct was injected into fly embryos, and transformed flies were isolated according to standard methods (Spradling 1986).

\section{Other molecular techniques}

Plasmid rescue from minipreparations of fly DNA was performed according to Pirrotta (1986). Other cloning techniques followed standard procedures, as in Maniatis et al. (1982).

\section{Acknowledgments}

We thank Joan Hooper for providing stocks, Sean Carroll for sending HS-Hairy, Pat O'Farrell for helpful discussions about the potential developmental role of $d p n$, John Emery for restriction analysis of the $d p n$ genomic locus, Robert P. Carretto, Sandra Barbel, and Jason O'Neil for help with tissue in situ hybridization and immunohistochemistry, Denise Muhlrad for assistance in DNA sequencing, Larry Ackerman for photography, and Barbara Bannerman and Katherine Prewitt for patient preparation of the manuscript. L.Y.J. and Y.N J. are Howard Hughes Medical Institute investigators.

The publication costs of this article were defrayed in part by payment of page charges. This article must therefore be hereby marked "advertisement" in accordance with 18 USC section 1734 solely to indicate this fact.

\section{References}

Akam, M. 1989. Hox and HOM: Homologous gene clusters in insects and vertebrates. Cell 57: 347-349.

Alonso, M.C. and C.V. Cabrera. 1988. The achaete-scute com- plex of Drosophila melanogaster comprises four homologous genes. EMBO /. 7: 2585-2591.

Artavanis-Tsakonas, S. and P. Simpson. 1991. Choosing a cell fate: A view from the Notch locus. Trends Genet. 7: 403407.

Baumgartner, S., D. Bopp, M. Burri, and M. Noll. 1987. Structure of two genes at the gooseberry locus related to the paired gene and their spacial expression during Drosophila embryogenesis. Genes \& Dev. 1: 1237-1267.

Bellen, H.J., C.J. O'Kane, C. Wilson, U. Grossniklaus, R. Pearson, and W.J. Gehring. 1989. P-element-mediated enhancer detection: A versatile method to study development in Drosophila. Genes \& Dev. 3: 1288-1300.

Benezra, R., R. L. Davis, D. Lockshon, D.L. Turner, and H. Weintraub. 1990. The protein Id: A negative regulator of helix-loop-helix DNA binding proteins. Cell 61: 49.

Bier, E., L. Ackerman, S. Barbel, L.Y. Jan, and Y.N. Jan. 1988. Identification and characterization of a neuron-specific nuclear antigen in Drosophila. Science 240: 913-916.

Bier, E., H. Vaessin, S. Shepherd, K. Lee, K. McCall, S. Barbel, L. Ackerman, R. Carretto, T. Uemura, E. Grell, L.Y. Jan, and Y.N. Jan. 1989. Searching for pattern and mutation in the Drosophila genome with a P-lacZ vector. Genes \& Dev. 3: 1273-1287.

Bier, E., L.Y. Jan, and Y.N. Jan. 1990. rhomboid, a gene required for dorsoventral axis establishment and peripheral nervous system development in Drosophila melanogaster. Genes \& Dev. 4: 190-203.

Blochlinger, K., R. Bodmer, J. Jack, L.Y. Jan, and Y.N. Jan. 1988. Primary structure and expression of a product from cut, a locus involved in specifying sensory organ identity. Nature 333: 629-635.

Bodmer, R., S. Barbel, S. Shepherd, J. Jack, L.Y. Jan, and Y.N. Jan. 1987. Transformation of sensory organs by mutations of the cut locus of D. melanogaster. Cell 51: 293-307.

Bodmer, R., R. Carretto, and Y.N. Jan. 1989. Neurogenesis of the peripheral nervous system in Drosophila melanogaster embryos: DNA replication patterns and cell lineages. Neuron 3: 21-32.

Bopp, D., M. Burri, S. Baumgartner, G. Frigerio, and M. Noll. 1986 Conservation of a large protein domain in the segmentation gene paired and in functionally related genes of Drosophila. Cell 47: 1033-1040.

Botas, J., J. Moscoso del Prado, and A. Garcia-Bellido. 1982. Gene dose titration analysis in the search of trans-regulatory genes in Drosophila. EMBO J. 1: 307-310.

Boulianne, G.B., A. de la Concha, J.A. Campos-Ortega, L.Y. Jan, and Y.N. Jan. 1991. The Drosophila neurogenic gene neuralized encodes a novel protein and is expressed in precursors of larval and adult neurons. EMBO I. 10: 2975-2983.

Boulay, J.L., C. Dennefeld, and A. Alberga. 1987. The Drosophila developmental gene snail encodes a protein with nucleic acid binding fingers. Nature: 330: 395-398.

Brand, M. and J.A. Campos-Ortega. 1988. Two groups of interrelated genes regulate early neurogenesis in Drosophila melanogaster. Roux's Arch. Dev. Biol. 197: 457-470.

1990. Second-site modifiers of the split mutation of Notch define genes involved in neurogenesis in Drosophila melanogaster. Roux's Arch. Dev. Biol. 198: 275-285.

Cabrera, C.V., A. Martinez-Arias, and M. Bate. 1987. The expression of three members of the achaete-scute gene complex correlates with neuroblast segregation in Drosophila. Cell 50: 425.

Campos-Ortega, J.A. and Y.N. Jan. 1991. Genetic and molecular basis of neurogenesis in Drosophila melanogaster. Annu. Rev. Neurosci. 14: 399-420. 
Carroll, S.B. and I. Whyte. 1989. The role of the hairy gene during Drosophila morphogenesis: Stripes in imaginal discs. Genes \& Dev. 3: 905-916.

Carroll, S.B., A. Laughon, and B. Thalley. 1988. Expression, function and regulation of the hairy segmentation protein in the Drosophila embryo. Genes \& Dev. 2: 883-890.

Caudy, M., E.H. Grell, C. Dambly-Chaudiere, A. Ghysen, L.Y. Jan, and Y.N. Jan. 1988a. The maternal sex determination gene daughterless has zygotic activity necessary for the formation of peripheral neurons in Drosophila. Genes \& Dev. 2: $843-852$

Caudy, M., H. Vaessin, M. Brand, R. Tuma, L.Y. Jan, and Y.N. Jan. 1988b. daughterless, a gene essential for both neurogenesis and sex determination in Drosophila has sequence similarities to myc and the achaete-scute complex. Cell 55: 1061-1067.

Cavener, D.R. 1987. Comparison of the consensus sequence flanking translation start sites in Drosophila and vertebrates. Nucleic Acids Res. 15: 1353-1361.

Cubas, P, J.F. de Celis, S. Campuzano, and J. Modolell. 1991 Proneural clusters of achaete-scute expression and the generation of sensory organs in the Drosophila imaginal wing disc. Genes \& Dev. 5: 996-1008.

Dambly-Chaudiere, C. and A. Ghysen. 1987. Independent subpatterns of sense organs require independent genes of the achaete-scute complex in Drosophila larvae. Genes \& Dev. 1: 297.

Dambly-Chaudiere, C., A. Ghysen, L.Y. Jan, and Y.N. Jan. 1988. The determination of sense organs in Drosophila: Interaction of scute with daughterless. Roux's Arch. Dev. Bio. 197: 419-423.

Dambly-Chaudiere, C., E. Jamet, M. Burri, D. Bopp. K. Basler, E. Hafen, N. Dumont, P. Spielmann, A. Ghysen, and M. Noll. 1992. The paired box gene pox neuro: A determinant of polyinnervated sense organs in Drosophila. Cell 69: 159-172.

Davis, I. and D. Ish-Horowitcz. 1992. Apical localization of pairrule transcripts requires $3^{\prime}$ sequences and limits protein diffusion in the Drosophila blastoderm embryo. Cell 67:927940.

de la Concha, A., U. Dietrich D. Weigle, and J.A. Campos-Ortega. 1988. Functional interactions of neurogenic genes of Drosophila melanogaster. Genetics 118: 499-508.

Davis, R., P.R. Cheng, A.B. Lassar, and H. Weintraub. 1990. The MyoD DNA binding domain contains a recognition code for muscle-specific gene activation. Cell 60: 733-746.

DePinho, R.A., K.S. Hatton, A. Tesfaye, G.D. Yancopoulos, and F.W. Alt. 1987. The human myc gene family: Structure and activity of L-myc and a L-myc pseudogene. Genes \& Dev. 1: 1311-1326.

Doe, C.Q. and C.S. Goodman. 1985. Early events in insect neurogenesis II. The role of cell interactions and cell lineage in the determination of neuronal precursor cells. Dev. Biol. 111: 206-219.

Doe, C.Q., D. Smouse, and C.S. Goodman. 1988a. Control of neuronal fate by the Drosophila segmentation gene evenskipped. Nature 333: 376-378.

Doe, C.Q., Y. Hiromi, W.J. Gehring, and C.S. Goodman. 1988b. Expression and function of the segmentation gene fushi tarazu during Drosophila neurogenesis. Science 239: 170175.

Doe, C.Q., Q. Chu-LaGraff, D.M. Wright, and M.P. Scott. 1991. The prospero gene specifies cell fates in the Drosophila central nervous system. Cell 65: 451-464.

Ellis, H.M., D.R. Spann, and J.W. Posakony. 1990. extramacrochaetae, a negative regulator of sensory organ development in Drosophila, defines a new class of helix-loop-helix pro- teins. Cell 61: 27-38.

Garrell, J. and J. Modelell. 1990. The Drosophila extramacrochaetae locus, and antagonist of proneural genes that, like these genes, encodes a helix-loop-helix protein. Cell 61: 39 48.

Ghysen, A. and C. Dambly-Chaudiere. 1989. Genesis of the Drosophila peripheral nervous system. Trends Genet. 5: 251.

Gonzalez, F., S. Romani, C. Cubas, J. Modolell, and S. Campuzano. 1989. Molecular analysis of the asense gene, a member of the achaete-scute complex of Drosophila melanogaster, and its novel role in optic lobe development. EMBO I. 8: 3553-3562.

Hartley, D.A., A. Preiss, and S. Artavanis-Tsakonas. 1988. A deduced gene product from the Drosophila neurogenic locus Enhancer of split shows homology to mammalian G-protein B subunit. Cell 55: 785-795.

Hopwood, N.D., A. Pluck, and J.B. Gurdon. 1989. Myo D expression in the forming somites is an early response to mesoderm induction in Xenopus embryos. EMBO f. 8: 34093417.

Ingham, P.W. 1988. The molecular genetics of embryonic pattern formation in Drosophila. Nature 335: 25-34.

Ingham, P.W., S.M. Pinchin, R.K. Howard, and D. Ish-Horowicz. 1985a. Genetic analysis of the hairy locus in Drosophila melanogaster. Genetics 111: 463-486.

Ingham, P.W., K.R. Howard, and D. Ish-Horowicz. 1985b. Transcription pattern of the Drosophila segmentation gene hairy. Nature 318: 439-445.

Jan, L.Y. and Y.N. Jan. 1982. Antibodies to horseradish peroxidase as specific neuronal markers in Drosophila and grasshopper embryos. Proc. Nat1. Acad. Sci. 79: 2700-2704.

- 1990. Genes required for specifying cell fates in Drosophila embryonic nervous system. Trends Neurosci. 13: 493498.

Jimenez, F. and J.A. Campos-Ortega. 1990. Defective neuroblast commitment in mutants of the achaete-scute complex and adjacent genes of $D$. melanogaster. Neuron 5: 81-89.

Johnson, J.E., S.J. Birren, and D.J. Anderson. 1990. Two rat homologues of Drosophila achaete-scute specifically expressed in neuronal precursors. Nature 346: 858-861.

Jürgens, G., E. Wieschaus, C. Nüsslein-Volhard, and H. Kluding. 1984. Mutations affecting the pattern of the larval cuticle in Drosophila melanogaster. II. Zygotic loci on the third chromosome. Wilhelm Roux's Arch. Dev. Biol. 193: 283-295.

Kidd, S., M.R. Kelley, and M.W. Young. 1986. Sequence of the Notch locus of Drosophila melanogaster: Relationship of the encoded protein to mammalian clotting and growth factors. Mol. Cell. Biol. 6: 3094 .

Klämbt, C. E. Knüst, K. Tietze, and J.A. Campos-Ortega. 1989. Closely related transcripts encoded by the neurogenic gene complex Enhancer of split of Drosophila melanogaster. EMBO I. 8: 203-210.

Knüst, E., K. Tietze, and J.A. Campos-Ortega. 1987. Molecular analysis of the neurogenic locus Enhancer of split of Drosophila melanogaster. EMBO \%. 6: 4113-4123.

Kohl, N.E., E. Legony, R.A. DePinho, P.D. Nisen, R.K. Smith, C.E. Gee, and F.W. Alt. 1986. Human N-myc is closely related in organization and nucleotide sequence to $\mathrm{C}-\mathrm{myc}$. $\mathrm{Na}$ ture 319: 73-77.

Kopezynski, C.C., A.K. Alton, K. Fechtel, P.J. Kooh, and M.A.T. Muskavitch. 1988. Delta, a Drosophila neurogenic gene, is transcriptionally complex and encodes a protein related to blood coagulation factors and epidermal growth factor and epidermal growth factor of vertebrates. Genes \& Dev. 2: 1723 . 
Kosman, D., Y.T. Ip, M. Levine, and K. Arora. 1991. Establishment of the mesoderm-neuroectoderm boundary in the Drosophila embryo. Science 254: 118-121.

Kruys, V., O. Marinx, G. Shaw, J. Deschamps, and G. Huez. 1989. Transition blockade imposed by cytokine-derived UArich sequences. Science 245: 852-854.

Lassar, A.B., J.N. Buskin, D. Lockshon, R.L. Davis, S. Apone, S.D. Hauschka, and H. Weintraub. 1989. Myo $D$ is a sequence-specific DNA binding protein requiring a region of myc homology to bind to the muscle creatine kinase enhancer. Cell 58: 823-831.

Lehner, C. and P. O'Farrell. 1989. Expression and function of Drosophila cyclin A during embryonic cell cycle progression. Cell 56: 957-968.

Lindsley, D.L. and E.H. Grell. 1968. Genetic variations in Drosophila melanogaster. Carnegie Inst. Washington Publ.

Lo, L.C., J.E. Johnson, C.W. Wuenschell, T. Saito, and D.J. Anderson. 1991. Mammalism achaete-scute homologue 1 is transiently expressed by spatially restricted subsets of early neuroepithelial and neural crest cells. Genes \& Dev. 5: $1524-1537$.

Malicki, J., K. Schughart, and W. McGinnis. 1990. Mouse Hox2.2 specifies thoracic segmental identity in Drosophila embryos and larvae. Cell 63: 961-967.

Maniatis, T., E.F. Fritsch, and J. Sambrook. 1982. Molecular cloning: A laboratory manual. Cold Spring Harbor Laboratory, Cold Spring Harbor, New York.

Martinez, C. and J. Modolell. 1991. Cross-regulatory interactions between the proneural achaete and scute genes of Drosophila. Science 251: 1485-1487.

Mayer, U. and C. Nüsslein-Volhard. 1988. A group of genes required for pattern formation in the ventral ectoderm of the Drosophila embryo. Genes \& Dev. 2: 1496-1511.

McGinnis, N., M.A. Kuziora, and W. McGinnis. 1990. Mouse Hox -4.2 and Drosophila deformed encode similar regulatory specificities in Drosophila embryos and larvae. Cell 63: 969976.

Michelson, A.M., S.M. Abmayr, M. Bate, A. Martinez Arias, and T. Maniatis. 1990. Expression of a $M y o D$ family member prefigures muscle pattern in Drosophila embryos. Genes \& Dev. 4: 2086-2097.

Mlodzik, M., N.E. Baker, and G. M. Rubin. 1990. Isolation and expression of scabrous, a gene regulating neurogenesis in Drosophila. Genes \& Dev. 4: 1848-1861.

Moscoso del Prado, J. and A. Garcia-Bellido. 1984. Genetic regulation of the achaete-scute complex of Drosophila melanogaster. Roux's Arch. Dev. Biol. 193: 242.

Murre, C., P. Schonoleber-McCaw, and D. Baltimore. 1989a. A new DNA binding and dimerization motif in immunoglobulin enhancer binding, daughterless, $M y o D$ and myc proteins. Cell 56: 777-783.

Murre, C., P. Schonleber-McCaw, H. Vaessin, M. Caudy, L.Y. Jan, Y.N. Jan, C.V. Cabrera, J.N. Buskin, S.D. Hauschka, A.B. Lassar, H. Weintraub, and D. Baltimore. 1989b. Interactions between heterologous helix-loop-helix proteins generate complexes that bind specifically to a common DNA sequence. Cell 58: 537-544.

Nambu, J.R., J.O. Lewis, K.A. Wharton, and S.T. Crews. 1991. The Drosophila single minded gene encodes a helix-loophelix protein that acts as a master regulator of CNS midline development. Cell 67: 1157-1167.

Nüsslein-Volhard, C, E. Weischaus, and H. Kluding, 1984. Mutations affecting the pattern of the larval cuticle in Drosophila melanogaster. I. Zygotic loci on the second chromosome. Wilhelm Roux's Arch. Dev. Biol. 183: 267-282.

O'Kane, C. and W. Gehring. 1987. Detection in-situ of genomic regulatory elements in Drosophila. Proc. Natl. Acad. Sci. 84: 9123-9127.

Parkhurst, S.M., D. Bopp, and D. Ish-Horowicz. 1990. X : A ratio, the primary sex-determining signal in Drosophila, is transduced by helix-loop-helix proteins. Cell 63: 1179-1191.

Patel, N.H., E. Martin-Blanco, K.G. Coleman, S.J. Poole, M.C. Ellis, T.B. Kornberg, and C.S. Goodman. 1989. Expression of engrailed proteins in arthropods, annelids, and chordates. Cell 58: 955-968.

Pirrotta, V. 1986. Cloning Drosophila genes. In Drosophila, a practical approach (ed. D.R. Roberts), pp. 83-110. IRL Press, Oxford, Washington, D.C.

Rao, Y., L.Y. Jan, and Y.N. Jan. 1990. Similarity of the product of the Drosophila neurogenic gene big brain to transmembrane channel proteins. Nature 345: 163-167.

Robinow, S. and K. White. 1988. The locus elav of Drosophila is expressed in neurons at all developmental stages. Dev. Biol. 126: 294-303.

Robinow, S., A.R. Campos, K.M. Yao, and K. White. 1988. The elav gene product of Drosophila, required in neurons, has three RNP consensus motifs. Science 242: 1570-1572.

Romani, S., S. Campuzano, and J. Modolell. 1987. The achaetescute complex is expressed in neurogenic regions of Drosophila embryos. EMBO J. 6: 2085-2092.

Romani, S., S. Campuzano, E.R. Macagno, and J. Modolell. 1989. Expression of achaete and scute genes in Drosophila imaginal discs and their function in sensory organ development. Genes \& Dev. 3: 997-1007.

Rosenberg, A.I., B.N. Lade, D. Chui, S.-W. Lin, J.J. Dun, and F.W. Studier. 1987. Vectors for the selective expression of cloned DNAs by T7 RNA polymerase. Gene 56: 125-135.

Rushlow, C.A., A. Hogan, S.M. Pinchin, K.M. Howe, M. Lardelli and D. Ish-Horowicz. 1989. The Drosophila protein acts in both segmentation and bristle patterning and shows homology to N-myc. EMBO /. 8: 3095-3103.

Sargent, M.G. and M.F. Bennett. 1990. Identification in Xenopus of a structural homologue of the Drosophila gene snail. Development 109: 967-973.

Schneuwly, S., R. Klemenz, and W. Gehring. 1987. Redesigning the body plan of Drosophila by ectopic expression of the homeotic gene Antennapedia. Nature 325: 816-818.

Shaw, G. and R. Kamen. 1986. A conserved AU sequence from the $3^{\prime}$ untranslated region of GM-CSF mRNA mediates selective mRNA degradation. Cell 46: 659-667.

Skeath, J.B. and S.B. Carroll. 1991. Regulation of achaete-scute gene expression and sensory organ pattern formation in the Drosophila wing. Genes \& Dev. 5: 984-995.

- 1992. Regulation of proneural gene expression and cell fate during neuroblast segregation in the Drosophila embryo. Development 114: 939-946.

Small, S., R. Kraut, T. Hoey. R. Warrior, and M. Levine. 1991. Transcriptional regulation of a pair rule stripe in Drosophila. Genes \& Dev. 5: 827-839.

Smoller, D., C. Friedel, A. Schmid, D. Bettler, L. Lam, and B. Yedvobnick. 1990. The Drosophila neurogenic locus master mind encodes a nuclear protein unusually rich in amino acid homopolymers. Genes \& Dev. 4: 1688-1700.

Spradling, A. 1986. P-element-mediated transformation. In Drosophila: A practical approach (ed. D.B. Roberts), pp. 175 197. IRL Press, Oxford, Washington, D.C.

Tautz, D. and C. Pfeifle. 1989. A nonradioactive in situ hybridization method for the localization of specific RNAs in Drosophila embryos reveals a translational control of segmentation gene hunchback. Chromosma 98: 81-85.

Thisse, B., C. Stoetzel, C. Gorostiza-Thisse, and F. PerrinSchmitt. 1988. Sequence of the twist gene and nuclear local- 
ization of its protein in endomesodermal cells of early Drosophila embryos. EMBO 1. 7: 2175-2183.

Tietze, K., N. Oellers, and E. Knust. 1992. Enhancer of split ${ }^{\mathrm{D}}$, a dominant mutation in Drosophila and its use in the study of functional domains of a helix-loop-helix protein. Proc. Natl. Acad. Sci. (in press).

Truman, J. and C.M. Bate. 1988. Spatial and temporal patterns of neurogenesis in the central nervous system of Drosophila melanogaster. Dev. Biol. 125: 145-157.

Vaessin, H., J. Vielmetter, and J.A. Campos-Ortega. 1985. Genetic interactions in early neurogenesis of Drosophila melanogaster. J. Neurogenet. 2: 291-308.

Vaessin, H., K.A. Bremer, E. Knust, and J.A. Campos-Ortega. 1987. The neurogenic locus Delta of Drosophila melanogaster is expressed in neurogenic territories and encodes a putative transmembrane protein with EGF-like repeats. EMBO I. 6: 3431-3440.

Vaessin, H., E. Grell, E. Wolff, E. Bier, L. Jan, and Y.N Jan. 1991. prospero is expressed in neuronal precursors and encodes a nuclear protein that is involved in the control of axonal outgrowth in Drosophila. Cell 67: 941-953.

Venkatesh, T.R., S.L. Zipursky, and S. Benzer. 1985. Molecular analysis of development of the compound eye in Drosophila. Trends Neurosci. 8: 251-257

Villares, R. and C.V. Cabrera. 1987. The achaete-scute gene complex of D. melanogaster: Conserved domains in a subset of genes required for neurogenesis and their homology to myc. Cell 50: 415-424.

Wharton, K.A., K.M. Johannen, R. Xu, and S. Artavanis-Tsakonas. 1985. Nucleotide sequence form the neurogenic locus Notch implies a gene product that shares homology with proteins containing EGF-like repeats. Cell 43: 567.

Xu, T.I., I. Rebay, R.J. Fleming, T.N. Scottgale, and S. Artavanis Tsakonas. 1990. The Notch locus and the genetic circuitry involved in early Drosophila neurogenesis. Genes \& Dev. 4: 464-475.

Younger-Shepherd, S., H. Vaessin, E. Bier, L.Y. Jan, and Y.N. Jan. 1992. deadpan, an essential pan-neural gene encoding an $\mathrm{HLH}$ protein, acts as a denominator in Drosophila sex determination. Cell 70: 911-922.

Ziemer, A., K. Tietze, and J.A. Campos-Ortega. 1988. Genetic analysis of Enhancer of split, a locus involved in neurogenesis in Drosophila melanogaster. Genetics 119: 63-74. 


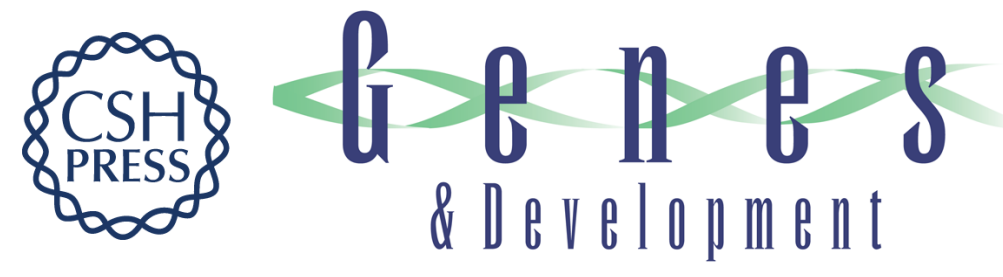

\section{deadpan, an essential pan-neural gene in Drosophila, encodes a helix-loop-helix protein similar to the hairy gene product.}

E Bier, H Vaessin, S Younger-Shepherd, et al.

Genes Dev. 1992, 6:

Access the most recent version at doi:10.1101/gad.6.11.2137

References This article cites 101 articles, 33 of which can be accessed free at: http://genesdev.cshlp.org/content/6/11/2137.full.html\#ref-list-1

License

Email Alerting

Receive free email alerts when new articles cite this article - sign up in the box at the top Service right corner of the article or click here.

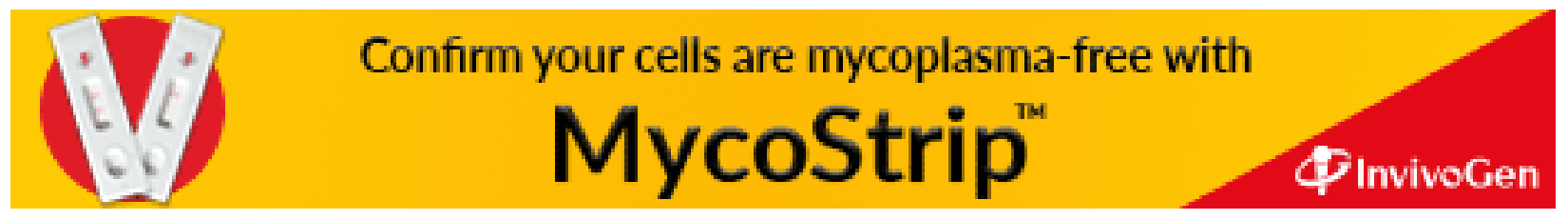

